\begin{tabular}{|c|c|c|}
\hline 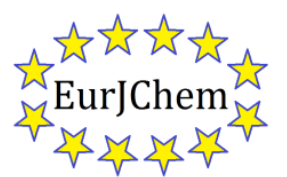 & $\begin{array}{c}\text { European Journal of Chemistry } \\
\text { Journal homepage: } \underline{\text { www.eurjchem.com }}\end{array}$ & 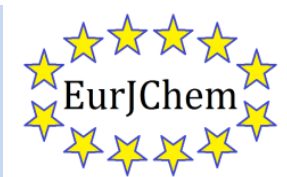 \\
\hline
\end{tabular}

\title{
Flotation-separation of toxic metal ions from aqueous solutions using thiosemicarbazide derivatives as chelating agents and oleic acid as a surfactant
}

\author{
Shaban El-Sayed Ghazy*, Gaber Mohamed Abu El-Reash, Ola Ahmed Al-Gammal and Tarek Yousef \\ Department of Chemistry, Faculty of ScienceMansoura University, Mansoura-35516, Egypt \\ *Corresponding author at: Department of Chemistry, Faculty of ScienceMansoura University, Mansoura-35516, Egypt. Tel.: +20502246254; fax: +20502246254. \\ E-mail-address: ghazyse@mans.edu.eg (S.E. Ghazy).
}

\section{ARTICLE INFORMATION}

Received: 27 February 2010

Received in revised form: 10 April 2010

Accepted: 3 May 2010

Online: 30 June 2010

\section{KEYWORDS}

\section{Mercury}

Manganese

Cadmium

Thiosemicabazide derivatives

Oleic acid

Natural water

\begin{abstract}
A simple and rapid procedure was developed for flotation-separation of toxic metal ions namely $\mathrm{Hg}^{2+}, \mathrm{Mn}^{2+}$ and $\mathrm{Cd}^{2+}$ from aqueous solutions. Thiosemicarbazide derivatives such as: 1-(amino- $N$-phenylmethanethio)-4-(pyridine-2-yl)thiosemicarbazide $\quad\left(\mathrm{H}_{2} \mathrm{PPS}\right), \mathrm{N}$-phenyl-2(pyridine-2-ylcarbamothioyl)hydrazinecarboxamide $\quad\left(\mathrm{H}_{2} \mathrm{PBO}\right), \quad$ 1-(amino(thioformyl)- $\mathrm{N}$ phenylform)-4-(pyridine-2-yl)thiosemicarbazide $\left(\mathrm{H}_{2} \mathrm{APO}\right)$, and 1-(amino- $\mathrm{N}$-(pyridine-3-yl) methanethio)-4-(pyridine-2-yl)thiosemicarbazide $\left(\mathrm{H}_{2} \mathrm{PPY}\right.$ ) have been used as organic chelating agents and oleic acid (HOL) as a surfactant. The different parameters affecting the flotation process namely, metal ion, ligands and surfactant concentrations, foreign ions (which are normally present in fresh and saline waters), $\mathrm{pH}$ and temperature are examined. About $100 \%$ of mercury, cadmium and manganese ions float at room temperature $\left(\sim 25^{\circ} \mathrm{C}\right)$, at a metal:ligand ratio of $1: 2$ and at $\mathrm{pH} \sim 5$. The procedure was successfully applied to recover $\mathrm{Hg}^{2+}, \mathrm{Mn}^{2+}$ and $\mathrm{Cd}^{2+}$ ions spiked into some water samples. The flotation mechanism is suggested based on some physical and chemical studies on the ligands and metal-complexes isolated from the floated layers.
\end{abstract}

\section{Introduction}

Toxic metal pollution is spreading throughout the world with the expansion of industrial activities [1]. These metals, which find many useful applications in our lives, are very harmful if they are discharged into natural water resources and may finally pose serious health hazards [2-4]. In other words, toxic metals which are of great environmental concern must be removed [5-7]. Industrial wastewater contains high levels of toxic metals and in order to avoid water pollution, treatment is needed before its disposal.

Mercury is considered to be a serious toxic metal pollutant [8]. Hg induced toxicity is related to differences in species, chemical form, specimen size and temperature, as well as other factors [9]. $\mathrm{Hg}^{2+}$ can be methylated to $\left(\mathrm{CH}_{3}\right)_{2} \mathrm{Hg}$ and $\mathrm{CH}_{3} \mathrm{Hg}^{+}$. Therefore, the longer the divalent inorganic mercurials remain in the environment, the more problematic the lipophilicity of the product-organic alkylmercury salt. Since the majority (often $100 \%$ ) of $\mathrm{Hg}$ in muscles is $\mathrm{CH}_{3} \mathrm{Hg}^{+}$species [9], little safety margin exists.

Cadmium, a heavy metal with limited biological function, is widely distributed in the aquatic environment as a result of natural and anthropogenic activities. Discharges containing cadmium are strictly controlled due to the highly toxic nature of this element and its tendency to accumulate in the tissues of living organisms. The harmful effects of cadmium include a number of chronic and acute disorders such as renal damage, emphysema, hypertension, high blood pressure, kidney damage and destruction of red blood cells $[8,10]$.

Manganese is an essential metal ion for life. It is a cofactor for a wide variety of enzymes, including the oxygen evolving complex, several kinases, phosphatases, synthetases and oxido- reductases [11]. Mn is an essential metal found in a variety of biological tissues and is necessary for normal functioning of a variety of physiological processes including amino acid, lipid, protein and carbohydrate metabolism [12]. It is also widely employed in industry (e.g. ferro-alloy plants), in agriculture (fertilizers and pesticides) and it has recently been introduced as an antiknock agent in unleaded gasoline. However, exposure to Mn may lead to accumulation in the basal ganglia of the brain, where it may have its neurotoxic effects [13]. Therefore, from the viewpoints of environmental chemistry, geochemistry and marine biology, it is important to establish a rapid and simple method for removing $\mathrm{Hg}^{2+}, \mathrm{Cd}^{2+}$ and $\mathrm{Mn}^{2+}$ ions from water.

Numerous techniques for the separation, removal and control of metal toxicants have been reported [8,14-16]. Although adsorption has been well established as a technology for removing toxic compounds from wastes or wastewaters, the process may face filter-blocking problems [16]. Also, sedimentation is a relatively slow process when dealing with biological materials that are usually of low density. Flotation as a separation process has recently received a considerable interest owing to its simplicity, rapidity, economy, good separation yields $(R>95 \%)$ at small concentrations $\left(10^{-6}-10^{-2}\right.$ mol L-1), and a large possibility of application for species having different nature and structure, flexibility and friability of equipment and processing for recovery purposes [17]. It is believed that this process will soon be incorporated as a clean technology to treat both water and wastewater [18]. Therefore, the flotation technique was used in this investigation.

Ion flotation involves the removal of surface-inactive ions (colligend) from aqueous solutions by adding surfactants which act as collectors. The subsequent passage of gas bubbles 
through the solution transfers the surface-active ions to the top [19]. Compared to other separation methods, ion flotation has advantages in its ease of operation and low costs. It shows particular promise for treating large volumes of dilute aqueous solutions [20].

Precipitate flotation is a foam separation process used to remove surface inactive substances from aqueous dispersions. The component to be removed is precipitated before the addition of a surfactant (collector). This may be accomplished by adding any substance that forms an insoluble compound. Since the surfactant needs only to react with ions on the surface, small amounts of collector is required [10]. Moreover, in this process the separation is obtained at the interface of the bulk and foam phases without the assistance from the extended phase, having the advantage of producing dry foam of small volume and thus allowing the use of compact equipment [10].

Electroflotation (ECF) technology could potentially present an alternative method for the removal of metals originating from products or machines facilities. ECF uses small bubbles obtained through aqueous solution electrolysis to float particles of a given size to the top. During the process, a cloud or blanket of finely dispersed gas bubbles is created with the help of two metallic electrodes (cathode/anode). The fine bubbles rise and attach to insoluble contaminant particles like metals or other organic substances. Part of the electrolytic products in the form of free radicals might also react with soluble organic matter and may cause considerable transformation. Several minutes into the process, coagulation begins which subsequently leads to the formation of a foamy layer that float to the top of the reaction vessel [21].

Although some work has been carried out for the flotation of $\mathrm{Hg}^{2+}[8,10,14,22-28] ; \mathrm{Cd}^{2+}[8,10,29-37]$ and $\mathrm{Mn}^{2+}[17,32,38-$ 43] from aqueous solutions, wastes and natural waters, no attention has been paid towards the use of thiosemicarbazide derivatives in this respect. Therefore, the objective of the present work was to extend the application of flotation technique to separate $\mathrm{Hg}^{2+}, \mathrm{Cd}^{2+}$ and $\mathrm{Mn}^{2+}$ ions from aqueous solutions using ( $\left.\mathrm{H}_{2} \mathrm{PPS}\right),\left(\mathrm{H}_{2} \mathrm{PBO}\right),\left(\mathrm{H}_{2} \mathrm{APO}\right),\left(\mathrm{H}_{2} \mathrm{PPY}\right)$ and oleic acid surfactant (HOL) under the recommended conditions.

\section{Experimental}

\subsection{Reagents}

Unless otherwise stated, all the chemicals used were of analytical grade and were used without further purification. Oleic acid (HOL) surfactant was used directly as received. Its stock solution $6.36 \times 10^{-2} \mathrm{~mol} \mathrm{~L}^{-1}$, was prepared from food grade with specific gravity 0.895 (J. T. Baker Chemical Co.) by dispersing $20 \mathrm{ml}$ in one liter of kerosene. Murcuric chloride $\left(\mathrm{HgCl}_{2}\right)$, manganese chloride $\left(\mathrm{MnCl}_{2}\right)$ and cadmium chloride $\left(\mathrm{CdCl}_{2}\right)$ stock solutions, $1 \times 10^{-2} \mathrm{~mol} \mathrm{~L}^{-1}$, each, were prepared by dissolving the calculated amounts in double distilled water. The stock solutions of the ligands $\mathrm{H}_{2} \mathrm{PPS}, \mathrm{H}_{2} \mathrm{PBO}, \mathrm{H}_{2} \mathrm{APO}$ and $\mathrm{H}_{2} \mathrm{PPY}$, $1 \times 10^{-2} \mathrm{~mol} \mathrm{~L}^{-1}$, each, were prepared in dioxane. The solids of these ligands were prepared by slowly adding pheny lisothiocyanate, phenylisocynate, benzoylisothiocyanate and 2-pyridylisothiocanate in absolute ethanol. The mixtures were refluxed on a water bath for a fixed time (30-120 min) depending on the reaction mixture. The products obtained were crystallized several times from absolute ethanol and dried in a vacuum desiccator over anhydrous $\mathrm{CaCl}_{2}$. The purity and properties of the ligands (Table 1) was checked by elemental analysis (Table 2) and IR (Table 3 ).

\subsection{Apparatus}

The flotation cell was a tube of $16 \mathrm{~mm}$ inner diameter and $290 \mathrm{~mm}$ in length with a quick fit stopper at the top and a stopcock at the bottom [44]. There are no instruments on the market for these techniques and because of the simplicity of the necessary devices, they are tailored according to the task in hand. Moreover, the following instruments are available in our Chemistry Department. The infrared spectra of the ligands, and their metal complexes were recorded on Mattson 5000 FTIR Spectrophotometer using $\mathrm{KBr}$ disc method. Spectrophotometric measurements were preformed using a Unicam UV-2100 spectrophotometer. The $\mathrm{pH}$ measurements were carried out using Hanna Instrument 8519 digital pH meter.

\subsection{Procedure}

A suitable aliquot containing a known amount of $\mathrm{Hg}^{2+}, \mathrm{Mn}^{2+}$ or $\mathrm{Cd}^{2+}$ specified for each investigation, was mixed with one of the thiosemicarbazide derivatives. The solution $\mathrm{pH}$ was adjusted with $\mathrm{HNO}_{3}$ and/or $\mathrm{NaOH}$ to the required value. The solution was then transferred to the flotation cell and the total volume was made up to $10 \mathrm{ml}$ with double distilled water. The cell was shaken well for $5 \mathrm{~min}$ to ensure complete complexation. To this, $2 \mathrm{~mL}$ of HOL (with known concentration) were added. The cell was then inverted upside down twenty times by hand. After 5 min standing for complete flotation, the concentration of the investigated metal ions in the mother liquors was determined spectrophotometrically using dithizone method at $485 \mathrm{~nm}$ (for $\mathrm{Hg}^{2+}$ ), potassium periodate oxidant in acidic medium at $528 \mathrm{~nm}$ (for $\mathrm{Mn}^{2+}$ ) and dithizone method at $520 \mathrm{~nm}$ (for $\mathrm{Cd}^{2+}$ ) [45].

The floatability ( $\mathrm{F} \%$ ) of each $\mathrm{M}^{2+}$ ion was calculated according to the relation :

$\mathrm{F} \%=\left(\mathrm{C}_{\mathrm{i}}-\mathrm{C}_{\mathrm{f}}\right) / \mathrm{Ci} \times 100$

where $\mathrm{C}_{\mathrm{i}}$ and $\mathrm{C}_{\mathrm{f}}$ denote the initial and the final concentrations of $\mathrm{M}^{2+}$ ion in the mother liquor, respectively.

\section{Results and Discussion}

Several experiments were carried out to investigate the floatability of $\mathrm{Hg}^{2+}, \mathrm{Mn}^{2+}$ and $\mathrm{Cd}^{2+}$ ions using only $\mathrm{HOL}$ as a surfactant. The floatability of $\mathrm{M}^{2+}$ ions does not exceed $40 \%$. Therefore, an enhancement of the process was required. Trials were made using some thiosemicarbazide derivatives as chelating agents. A number of reports concerning thiosemicarbazides and their metal complexes were established owing to their chemical and biological activities [46]. Really, an important number of thiosemicarbazides possess carciostatic efficacy and substantial in vivo activity against various human tumor lines [47]. Encouraging flotation results were attained using ( $\left.\mathrm{H}_{2} \mathrm{PPS}\right),\left(\mathrm{H}_{2} \mathrm{PBO}\right),\left(\mathrm{H}_{2} \mathrm{APO}\right)$ and $\left(\mathrm{H}_{2} \mathrm{PPY}\right)$ for $\mathrm{Hg}^{2+}$ ions; $\left(\mathrm{H}_{2} \mathrm{PPS}\right)$ and $\left(\mathrm{H}_{2} \mathrm{APO}\right)$ for $\mathrm{Mn}^{2+}$ ions and $\left(\mathrm{H}_{2} \mathrm{PPY}\right)$ for $\mathrm{Cd}^{2+}$ ions flotation.

\subsection{Effect of $\mathrm{pH}$}

$\mathrm{pH}$ is an important factor influencing flotation process since it affects not only the degree of ionization of metal ions, chelating agents and surfactants but also the speciation of the heavy metal ions in solution. The metal ions in aqueous solution are converted to different insoluble hydrolysis products due to changes in $\mathrm{pH}$. Several experiments were carried out to investigate the floatability of $2 \times 10^{4-} \mathrm{mol} \mathrm{L}^{-1}$ of $\mathrm{Hg}^{2+}, \mathrm{Mn}^{2+}$ and $\mathrm{Cd}^{2+}$ ions vs. solution $\mathrm{pH}$ using $4 \times 10^{-4} \mathrm{~mol} \mathrm{~L}^{-1}$ of each thiosemicarbazide derivative and $1 \times 10^{-3} \mathrm{~mol} \mathrm{~L}^{-1} \mathrm{HOL}$. The results obtained are plotted in Fig. 1 (A, B, and C). It can be seen that, maximal floatability of $\mathrm{Hg}^{2+}$ ions $(\sim 100 \%)$ were attained in the $\mathrm{pH}$ ranges of 4-6, 4-8, 3-10 and 4-9 using ( $\left.\mathrm{H}_{2} \mathrm{PPS}\right),\left(\mathrm{H}_{2} \mathrm{PBO}\right)$, $\left(\mathrm{H}_{2} \mathrm{APO}\right)$ and $\left(\mathrm{H}_{2} \mathrm{PPY}\right)$, respectively (Figure $\left.1 \mathrm{~A}\right)$. Moreover, maximal floatability $(\sim 100 \%)$ of $\mathrm{Mn}^{2+}$ (Figure $1 \mathrm{~B}$ ) and $\mathrm{Cd}^{2+}$ (Figure 1C) ions were attained in the $\mathrm{pH}$ ranges of 2-6 using $\left(\mathrm{H}_{2} \mathrm{PPS}\right)$ and $\left(\mathrm{H}_{2} \mathrm{APO}\right)$ and of 4-7 using $\left(\mathrm{H}_{2} \mathrm{APO}\right)$, respectively. 
Table 1. Physical properties of the prepared ligands.

\begin{tabular}{|c|c|c|c|c|c|}
\hline Compound & Color & Solvent & M.p. $\left({ }^{\circ} \mathrm{C}\right)$ & Yeild(\%) & Formula \\
\hline$\overline{\mathrm{H}_{2} \mathrm{PPS}}$ & yellow & Dioxane,DMF & 180 & 78 & $\mathrm{C}_{13} \mathrm{H}_{13} \mathrm{~N}_{5} \mathrm{~S}_{2}$ \\
\hline $\mathrm{H}_{2} \mathrm{PBO}$ & yellow & Dioxane,DMF & 270 & 81 & $\mathrm{C}_{13} \mathrm{H}_{13} \mathrm{~N}_{5} \mathrm{SO}$ \\
\hline $\mathrm{H}_{2} \mathrm{APO}$ & white & Dioxane,DMF & 182 & 79 & $\mathrm{C}_{14} \mathrm{H}_{13} \mathrm{~N}_{5} \mathrm{~S}_{2} \mathrm{O}$ \\
\hline $\mathrm{H}_{2} \mathrm{PPY}$ & yellow & Dioxane,DMF & 310 & 82 & $\mathrm{C}_{12} \mathrm{H}_{12} \mathrm{~N}_{6} \mathrm{~S}_{2}$ \\
\hline
\end{tabular}

Table 2. Chemical analysis of the prepared ligands.

\begin{tabular}{|c|c|c|c|c|c|c|}
\hline \multirow{2}{*}{ Compound } & \multirow{2}{*}{ Mol. Wt. } & \multicolumn{5}{|c|}{ \% Calc. (Found) } \\
\hline & & $\mathrm{C}$ & $\mathrm{H}$ & $\mathrm{N}$ & 0 & $\mathrm{~S}$ \\
\hline $\mathrm{C}_{13} \mathrm{H}_{13} \mathrm{~N}_{5} \mathrm{~S}_{2}\left(\mathrm{H}_{2} \mathrm{PPS}\right)$ & 303.41 & $51.46(51.13)$ & $4.32(4.25)$ & $23.08(22.96)$ & - & $21.14(21.11)$ \\
\hline $\mathrm{C}_{13} \mathrm{H}_{13} \mathrm{~N}_{5} \mathrm{OS}\left(\mathrm{H}_{2} \mathrm{PBO}\right)$ & 287.34 & $54.34(54.15)$ & $4.56(4.45)$ & 24.37 (23.98) & $5.57(5.40)$ & $11.16(11.11)$ \\
\hline $\mathrm{C}_{14} \mathrm{H}_{13} \mathrm{~N}_{5} \mathrm{OS}_{2}\left(\mathrm{H}_{2} \mathrm{APO}\right)$ & 331.42 & $50.74(50.35)$ & $3.95(3.47)$ & $21.13(21.78)$ & $4.83(4.80)$ & $19.35(19.31)$ \\
\hline $\mathrm{C}_{12} \mathrm{H}_{12} \mathrm{~N}_{6} \mathrm{~S}_{2}\left(\mathrm{H}_{2} \mathrm{PPY}\right)$ & 304.06 & $47.35(47.02)$ & $3.97(4.05)$ & $27.61(27.86)$ & - & $21.07(21.31)$ \\
\hline
\end{tabular}

Table 3. Assignment of important bands in the infrared spectra of the prepared ligands.

\begin{tabular}{|c|c|c|c|c|c|c|}
\hline Compound & $v(C=S)$ & $v(\mathrm{NH}) \mathrm{a}, \mathrm{a}^{\prime}$ & $v(\mathrm{NH}) \mathrm{b}, \mathrm{c}$ & $v(C=N)$ py & $v(C=C)$ & $v(C=0)$ \\
\hline $\mathrm{H}_{2} \mathrm{PPS}$ & $1223,755,850$ & 3099 & 3160 & 1569 & 1598 & - \\
\hline $\mathrm{H}_{2} \mathrm{PBO}$ & $1247,775,800$ & 3170,3104 & 3220 & 1641 & 1600 & 1672 \\
\hline $\mathrm{H}_{2} \mathrm{APO}$ & $1243,701,865$ & 3158,3100 & 3239 & 1542 & 1604 & 1675 \\
\hline $\mathrm{H}_{2} \mathrm{PPY}$ & $1218,900,750$ & 3174 & 3234 & 1562 & 1604 & - \\
\hline
\end{tabular}

This facilitates the application of some of the investigated thiosemicarbazide derivatives for the separation of $\mathrm{Hg}^{2+}, \mathrm{Mn}^{2+}$ and $\mathrm{Cd}^{2+}$ ions from acidic, neutral and alkaline mediums. The common $\mathrm{pH}$ range in which all the thiosemisarbazide derivatives gave maximal flotation of the investigated metal ions was found to be in the range of 4-6. Hence, $\mathrm{pH} \sim 5$ was fixed for further experiments for the flotation-separation of $\mathrm{Hg}^{2+}, \mathrm{Mn}^{2+}$ and $\mathrm{Cd}^{2+}$ ions.

\subsection{Effect of metal ion and ligand concentrations}

Attempts were carried out to float different concentrations of $\mathrm{Hg}^{2+}, \mathrm{Mn}^{2+}$ and $\mathrm{Cd}^{2+}$ ions using $4 \times 10^{-4} \mathrm{~mol} \mathrm{~L}^{-1}$ of each thiosemicarbazide derivative and $1 \times 10^{-3} \mathrm{~mol} \mathrm{~L}^{-1} \mathrm{HOL}$ at $\mathrm{pH} \sim 5$. The results obtained (Figure 2A, 2B, and 2C) show that the maximum flotation efficiency $(\sim 100 \%)$ of these metal ions were obtained for all the investigated thiosemicarbazide derivatives whenever the ratio of (M:L) is 1:1 for some thiosemicarbazides or 1:2 for others. Moreover, when the ratio is smaller than $1: 2$, all the chelating agents gave quantitative separation of $\mathrm{Hg}^{2+}$, $\mathrm{Mn}^{2+}$ and $\mathrm{Cd}^{2+}$ ions which may be attributed to the presence of sufficient amounts of thiosemicarbazide derivatives to bind all the investigated metal ions. At high metal ion concentration more than the ratio of $1: 1$, the flotation begins to decrease.

Another series of experiments were conducted to investigate the collecting ability of $\left(\mathrm{H}_{2} \mathrm{PPS}\right),\left(\mathrm{H}_{2} \mathrm{PBO}\right),\left(\mathrm{H}_{2} \mathrm{APO}\right)$ and $\left(\mathrm{H}_{2} \mathrm{PPY}\right)$ towards $\mathrm{Hg}^{2+}, \mathrm{Mn}^{2+}$ and $\mathrm{Cd}^{2+}$ ions using different concentrations of thiosemicarbazide derivatives and $1 \times 10^{-3} \mathrm{~mol}$ $\mathrm{L}^{-1} \mathrm{HOL}$ at $\mathrm{pH} \sim 5$. The data presented in Figure 3 (A, B and $\mathrm{C}$ ) show that, the floatability of metal ions increases abruptly reaching its maximum value $(\sim 100 \%)$ at $\mathrm{M}$ :L ratio of $(1: 1)$ Moreover, excess ligands have no adverse effect on the flotation process, thus facilitating the separation of $\mathrm{Hg}^{2+}, \mathrm{Mn}^{2+}$ and $\mathrm{Cd}^{2+}$ ions from unknown matrices; $4 \times 10^{-4} \mathrm{~mol} \mathrm{~L}^{-1}$ of each thiosemicarbazide derivative was used throughout.

\subsection{Effect of surfactant concentration}

Trials were carried out to float $\mathrm{Hg}^{2+}, \mathrm{Mn}^{2+}$ and $\mathrm{Cd}^{2+}$ ions with HOL only, but the recovery does not exceed $40 \%$, as shown in curve $\mathrm{b}$ (Figure 4A). Therefore, another series of experiments were performed to float $2 \times 10^{4-} \mathrm{mol} \mathrm{L}^{-1}$ of $\mathrm{Hg}^{2+}, \mathrm{Mn}^{2+}$ and $\mathrm{Cd}^{2+}$ ions in the presence of $4 \times 10^{-4} \mathrm{~mol} \mathrm{~L}^{-1}$ of each thiosemicarbazide derivative and different concentrations of HOL at $\mathrm{pH} \sim 5$. The results depicted in Figure 4 (A, B, and $\mathrm{C}$ ) show that in the HOL concentration range of $1 \times 10^{-3}-6 \times 10^{-2} \mathrm{molL}^{-1}$, complete floatation of $\mathrm{Hg}^{2+}, \mathrm{Mn}^{2+}$ and $\mathrm{Cd}^{2+}$ ions was achieved, below which the flotation decreases. This may be attributed to the presence of insufficient amounts of surfactant required for complete flotation.
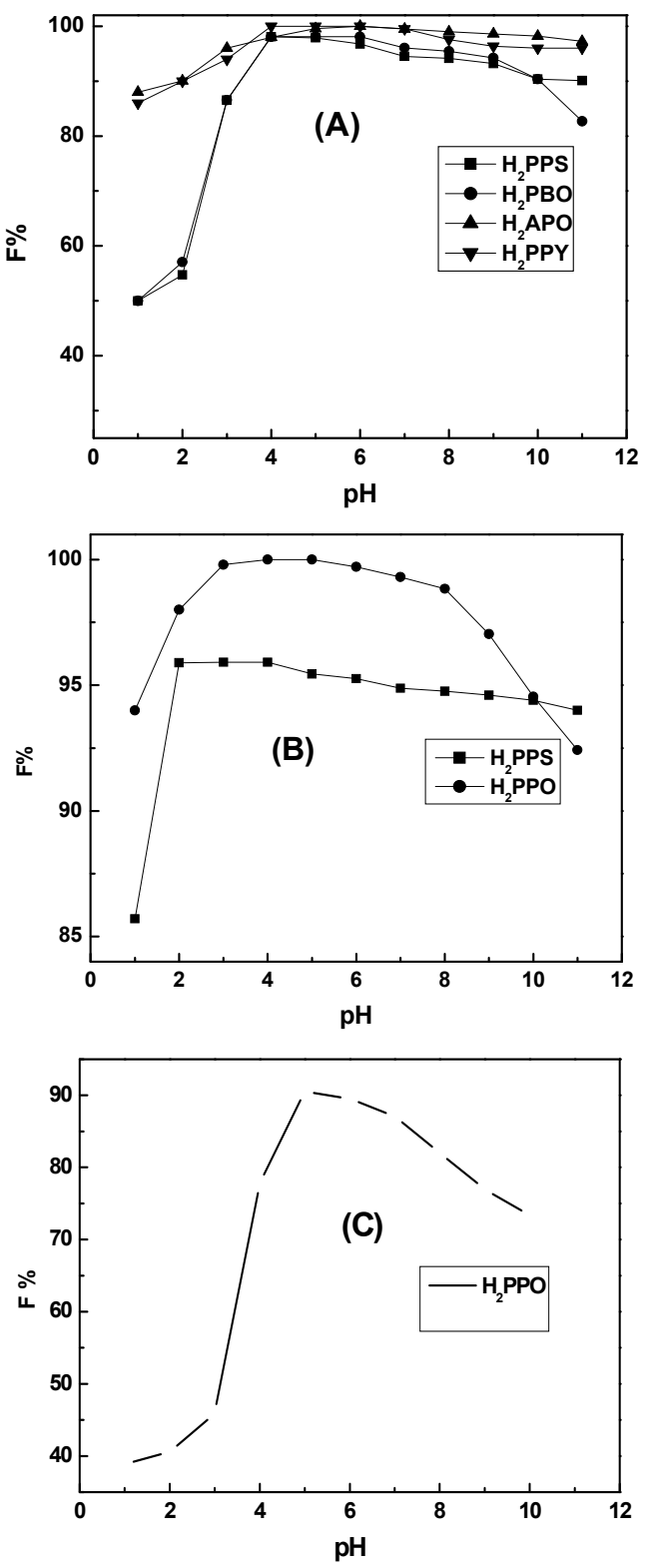

Figure 1. Effect of $\mathrm{pH}$ on the floatability of $2 \times 10^{-4} \mathrm{~mol} \mathrm{~L}^{-1}$ (A) $\mathrm{Hg}^{2+}$ ions; (B) $\mathrm{Mn}^{2+}$ ions and (C) $\mathrm{Cd}^{2+}$ ions using $4 \times 10^{-4} \mathrm{~mol} \mathrm{~L}^{-1}$ of each thiosemicarbazide derivative and $1 \times 10^{-3} \mathrm{~mol} \mathrm{~L}^{-1} \mathrm{HOL}$ 

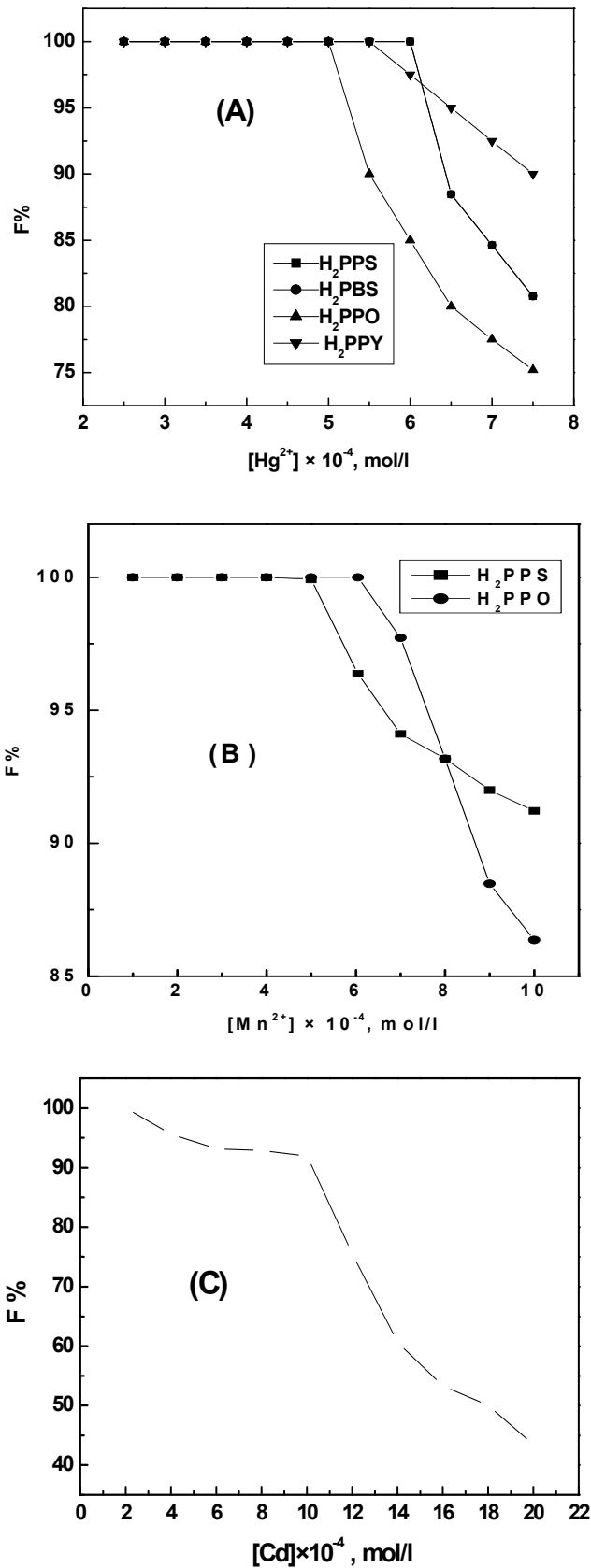

Figure 2. Floatability of different concentrations of (A) $\mathrm{Hg}^{2+}$ ions; (B) $\mathrm{Mn}^{2+}$ ions and (C) $\mathrm{Cd}^{2+}$ ions using $4 \times 10^{-4} \mathrm{~mol} \mathrm{~L}^{-1}$ of each thiosemicarbazide derivative and $1 \times 10^{-3} \mathrm{~mol} \mathrm{~L}^{-1} \mathrm{HOL}$ at $\mathrm{pH} \sim 5$.

At higher surfactant concentration the incomplete flotation of $\mathrm{Hg}^{2+}, \mathrm{Mn}^{2+}$ and $\mathrm{Cd}^{2+}$ ions may be due to the fact that the surfactant changes the state of the particles, M-thiosemi carbazide precipitates, from coagulation precipitation through coagulation flotation to re-dispersion with an increase in the amount of HOL added [48]. Moreover, the poor flotation at high surfactant concentration is caused by the formation on the air bubble surface of a stable, hydrated envelope of surfactant or, by forming a hydrate micelle coating on the solid surface [49]. As a result, the hydrophobicity of this surface was not satisfactory for flotation. Therefore, a concentration of $1 \times 10^{-3}$ mol L-1 of HOL was fixed throughout.

\subsection{Effect of temperature}

Under the recommended conditions, a series of experiments was conducted to float $\mathrm{Hg}^{2+}, \mathrm{Mn}^{2+}$ and $\mathrm{Cd}^{2+}$ ions at a wide range of temperatures. In order to do this, a solution of $\mathrm{Hg}^{2+}, \mathrm{Mn}^{2+}$ or $\mathrm{Cd}^{2+}$ ions, the thiosemicarbazide derivative and another containing HOL was either heated or cooled to the same temperature in a water bath. The HOL solution was quickly poured into $\mathrm{Hg}^{2+}, \mathrm{Mn}^{2+}$ or $\mathrm{Cd}^{2+}$ solution. The mixture was introduced into the flotation cell jacketed with $1 \mathrm{~cm}$ thick fiberglass insulation. The flotation procedure was then followed. The obtained results (Table 4) clarified that only $\mathrm{H}_{2} \mathrm{PPS}, \mathrm{H}_{2} \mathrm{PBO}$ and $\mathrm{H}_{2} \mathrm{APO}$ showed maximum flotation $(\sim 100 \%)$ of $\mathrm{Hg}^{2+}$ ions in the range of $5-85^{\circ} \mathrm{C}$, while $\mathrm{H}_{2} \mathrm{PPY}$ gave its maximum flotation in the temperature range of $25-65^{\circ} \mathrm{C}$. Moreover, the maximum separation $(\sim 100 \%)$ of $\mathrm{Mn}^{2+}$ and $\mathrm{Cd}^{2+}$ ions were achieved at $5{ }^{\circ} \mathrm{C}$ to $65^{\circ} \mathrm{C}$ using $\mathrm{H}_{2} \mathrm{PPS}$ and $\mathrm{H}_{2} \mathrm{APO}$ for $\mathrm{Mn}^{2+}$ and $\mathrm{H}_{2} \mathrm{APO}$ for $\mathrm{Cd}^{2+}$ ion. Therefore, $25^{\circ} \mathrm{C}$ is common between the four ligands and was used throughout.
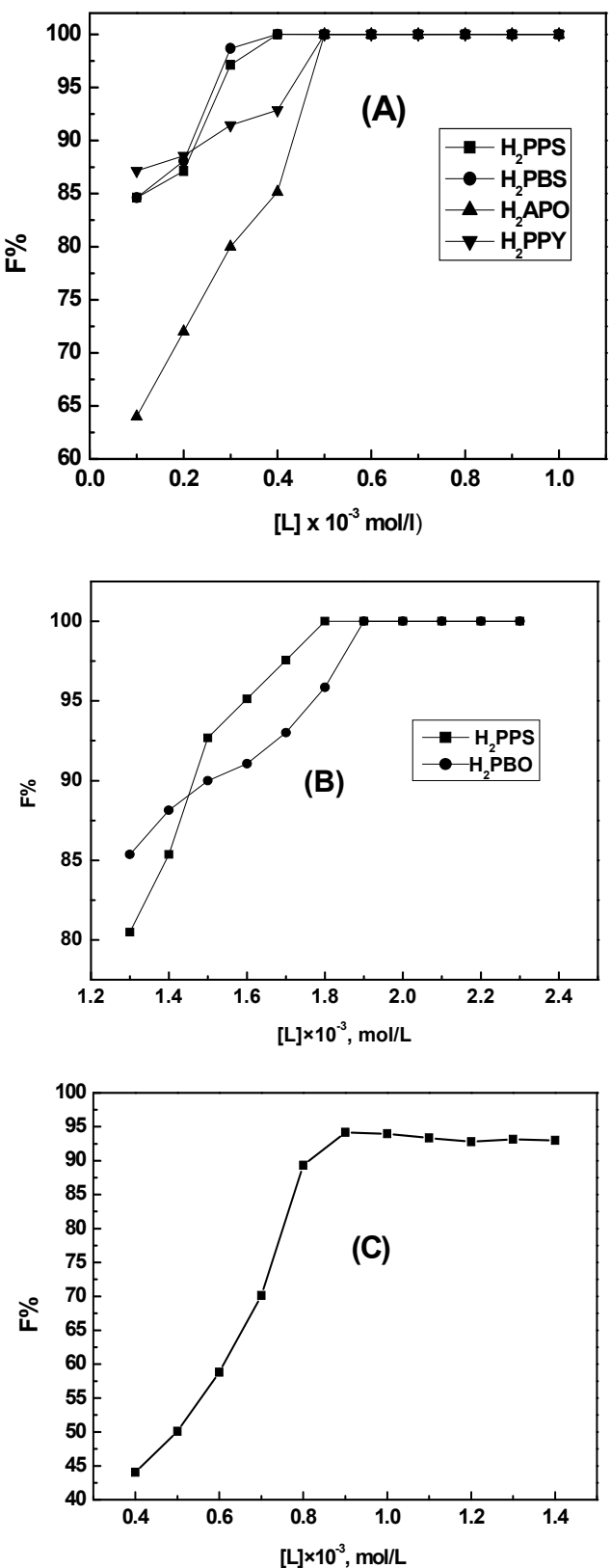

Figure 3. Floatability of $2 \times 10^{-4} \mathrm{~mol} \mathrm{~L}^{-1}$ (A) $\mathrm{Hg}^{2+}$ ions; (B) $\mathrm{Mn}^{2+}$ ions and (C) $\mathrm{Cd}^{2+}$ ions using different concentrations of each thiosemicarbazide derivative and $1 \times 10^{-3} \mathrm{~mol} \mathrm{~L}^{-1} \mathrm{HOL}$ at $\mathrm{pH} \sim 5$. 

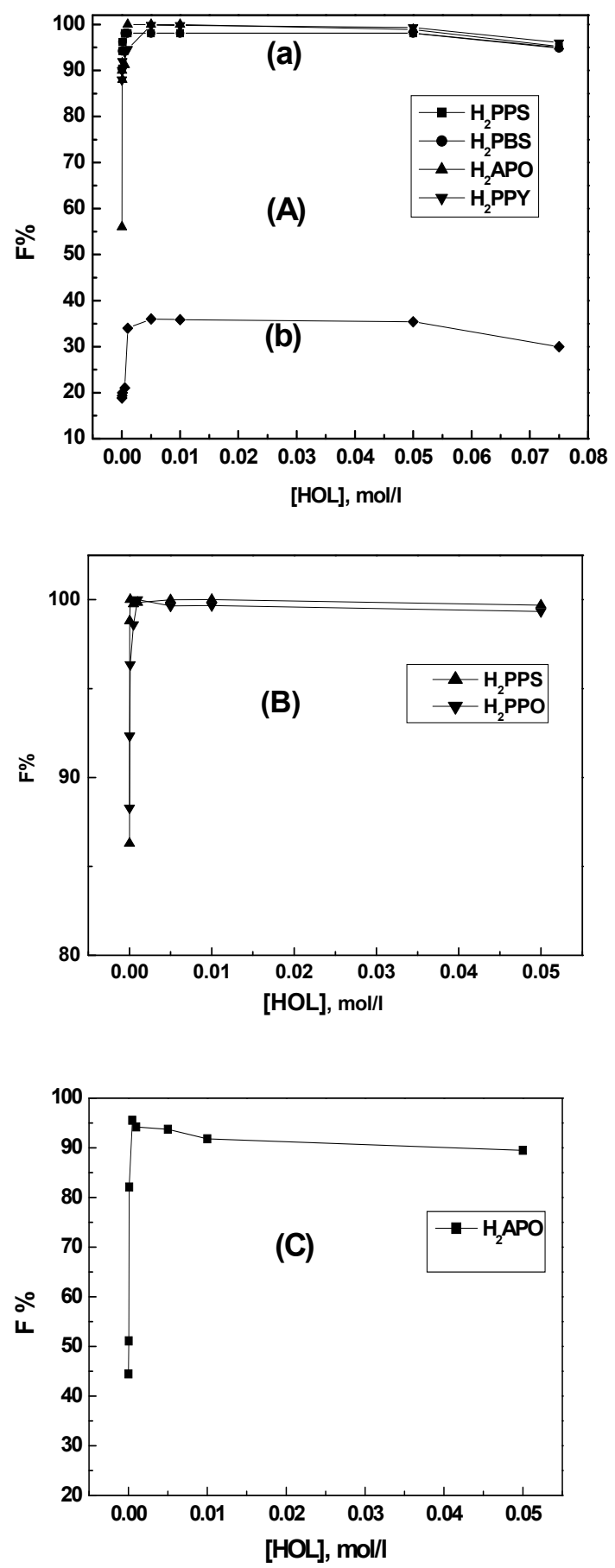

Figure 4. Floatability of $2 \times 10^{-4} \mathrm{~mol} \mathrm{~L}^{-1}(\mathrm{~A}) \mathrm{Hg}^{2+}$ ions in the absence (b) and presence (a) of $\mathrm{HOL}$; (B) $\mathrm{Mn}^{2+}$ ions and (C) $\mathrm{Cd}^{2+}$ ions using different concentrations of HOL and $2 \times 10^{-4} \mathrm{~mol} \mathrm{~L}^{-1}$ of each thiosemicarbazide derivative at $\mathrm{pH} \sim 5$.

The decrease in separation upon raising the temperature may be due to the increase in the solubility of the precipitate and the instability of the foam giving rise to partial dissolution of the precipitate and insufficient foam consistency to hold up the precipitate [27]. Since this parameter has an important and variable influence on the flotation process, it is very interesting to study each particular case, especially for large temperature variations [50].

\subsection{Effect of foreign ions}

In order to assess the applicability of the proposed method to recover $\mathrm{Hg}^{2+}, \mathrm{Mn}^{2+}$ and $\mathrm{Cd}^{2+}$ ions added to water samples, the effect of some foreign ions on the floatability of the investigated metal ions was carried out. These foreign ions were selected on the basis that they are normally present in fresh and saline waters. Solutions containing various amounts of foreign ions, $\mathrm{Hg}^{2+}, \mathrm{Mn}^{2+}$ and $\mathrm{Cd}^{2+}$ ions and each of the ligands were subjected to the described flotation procedure. The tolerable amounts of each ion, giving a maximum error of $\pm 2 \%$ in the floatability, are summarized in Table 5. As can be seen, all of the investigated foreign ions with relatively high concentrations (in comparison with that of $\mathrm{Hg}^{2+}, \mathrm{Mn}^{2+}$ and $\mathrm{Cd}^{2+}$ ions) have no adverse effect on the flotation of the investigated metal ions. Therefore, the recommended procedure may find its applications on water samples.

\subsection{Flotation of metal ions from different volumes}

Under the recommended conditions of the proposed procedure, the floatabilities of $2 \times 10^{-4} \mathrm{~mol} \mathrm{~L}^{-1}$ of $\mathrm{Hg}^{2+}, \mathrm{Mn}^{2+}$ and $\mathrm{Cd}^{2+}$ ions from different volumes of aqueous solutions (10 to $2000 \mathrm{~mL}$ ) in the presence of $4 \times 10^{-4} \mathrm{~mol} \mathrm{~L}^{-1}$ of each thiosemicarbazide derivative and $1 \times 10^{-3} \mathrm{~mol} \mathrm{~L}^{-1} \mathrm{HOL}$ at $\mathrm{pH} \sim 5$ were carried out. The obtained results showed that about $100 \%$ of the analytes were floated from the volumes of 10 to $1500 \mathrm{~mL}$ above which the floatability slightly decreased.

\subsection{Application}

In order to evaluate the capability of the flotation method for the flotation of $\mathrm{Hg}^{2+}, \mathrm{Mn}^{2+}$ and $\mathrm{Cd}^{2+}$ ions from water, various types of water samples were selected (i.e. soft, fresh and hard water). The selection of these samples was done in a way to provide a wide variety of sample matrices, characterized by different types of interferents. Solutions of pre-filtered water samples $\left(10 \mathrm{~mL}\right.$, each) containing $\mathrm{Hg}^{2+}, \mathrm{Mn}^{2+}$ and $\mathrm{Cd}^{2+}$ ions with a concentration of 5 or $10 \mathrm{mg} \mathrm{L}^{-1}$ were floated under the recommended conditions. The data obtained are given in Table 6. It is clear that satisfactory flotation results of $\mathrm{Hg}^{2+}, \mathrm{Mn}^{2+}$ and $\mathrm{Cd}^{2+}$ ions were obtained.

\section{Flotation mechanism}

The mechanism of the flotation of metal-thiosemicarbazide precipitates is suggested depending on the following:

$\mathrm{Hg}^{2+}, \mathrm{Mn}^{2+}$ and $\mathrm{Cd}^{2+}$ ions react with the investigated thiosemicarbazide derivatives in a M:L raio of $1: 1$ and $1: 2$ to give the complexes $\mathrm{MHL}^{+}$and $\mathrm{M}(\mathrm{HL})_{2}$ according to the following equations:

$$
\begin{aligned}
& \mathrm{M}^{2+}+\mathrm{H}_{2} \mathrm{~L} \rightarrow \mathrm{HgHL}^{+}+\mathrm{H}^{+} \\
& \mathrm{M}^{2+}+2 \mathrm{H}_{2} \mathrm{~L} \rightarrow \mathrm{Hg}(\mathrm{HL})_{2}+2 \mathrm{H}^{+}
\end{aligned}
$$

These equations were confirmed by elemental analyses of C, $\mathrm{H}, \mathrm{N}, \mathrm{O}$ and $\mathrm{S}$. These complexes have many sites containing electronegative atoms, such as oxygen, sulfur and nitrogen in the form of $\mathrm{C}=\mathrm{O}, \mathrm{C}=\mathrm{S}, \mathrm{NH}$ and $\mathrm{C}=\mathrm{N}$, functional groups as shown in Table 3, capable of forming hydrogen bonds.

The nature of the chemical species of oleic acid in the solution is determined by $\mathrm{pH}$ as the degree of dissociation is governed by $\mathrm{pH}$ [51]. Oleic acid begins to dissociate at $\mathrm{pH}>5.2$ [48] and the percentage of different forms of oleic acid are determined by IR analysis and the data are reported [52]. As a representative example the percentage of different forms of oleic acid determined by IR analysis at $\mathrm{pH} 9$ (adjusted by $\mathrm{NaOH}$ ) are: $13.2 \%$ oleic acid, $68.2 \%$ oleate and $18.2 \%$ sodium oleate [52]. The IR spectra of oleic acid with changing $\mathrm{pH}$ indicated that at $1300-1800 \mathrm{~cm}^{-1}$, there are bands characteristic of the groups $\mathrm{CO}_{2} \mathrm{H}, \mathrm{CO}_{2}-$ and $\mathrm{CO}_{2}^{-}$contained with $\mathrm{Na}$ [52]. These data agree with those reported [49] that the $\mathrm{C}=0$ stretching band of oleic acid at $1705 \mathrm{~cm}^{-1}$ is shifted on ionization to bands in the range of 
Table 4. Floatability of $2 \times 10^{-4} \mathrm{~mol} \mathrm{~L}^{-1}$ of $\mathrm{Hg}^{2+}, \mathrm{Mn}^{2+}$ and $\mathrm{Cd}^{2+}$ ions at different temperatures using $4 \times 10^{-4} \mathrm{~mol} \mathrm{~L}^{-1}$ of each thiosemicarbazide derivative and $1 \times 10^{-3}$ mol L-1 HOL at $\mathrm{pH} \sim 5$.

\begin{tabular}{|c|c|c|c|c|c|c|c|}
\hline \multirow[t]{2}{*}{ Temperature, ${ }^{\circ} \mathrm{C}$} & \multicolumn{4}{|c|}{ Hg $^{2+}$ Floatability, (\%) } & \multicolumn{2}{|c|}{ Mn'+Floatability, (\%) } & \multirow{2}{*}{$\begin{array}{c}\text { Cd }^{2+}, \text { Floatability, (\%) } \\
\mathrm{H}_{2} \mathrm{APO}\end{array}$} \\
\hline & $\mathrm{H}_{2} \mathrm{PPS}$ & $\mathrm{H}_{2} \mathrm{PBO}$ & $\mathrm{H}_{2} \mathrm{APO}$ & $\mathrm{H}_{2} \mathbf{P P Y}$ & $\mathrm{H}_{2} \mathrm{PPS}$ & $\mathrm{H}_{2} \mathrm{APO}$ & \\
\hline 5 & 99.0 & 99.0 & 99.1 & 80.0 & 99.0 & 99.1 & 99.1 \\
\hline 10 & 99.2 & 99.6 & 99.2 & 83.7 & 99.2 & 99.2 & 99.2 \\
\hline 25 & 100.0 & 100.0 & 100.0 & 100.0 & 100.0 & 100.0 & 100.0 \\
\hline 35 & 100.0 & 100.0 & 99.3 & 100.00 & 100.0 & 99.3 & 99.3 \\
\hline 45 & 99.9 & 99.9 & 99.9 & 99.9 & 99.9 & 99.9 & 99.9 \\
\hline 55 & 99.8 & 99.7 & 99.8 & 99.6 & 99.8 & 99.8 & 99.8 \\
\hline 65 & 99.9 & 99.8 & 99.5 & 97.9 & 99.9 & 99.5 & 99.5 \\
\hline 75 & 99.7 & 99.7 & 99.7 & 53.9 & 99.7 & 99.7 & 99.7 \\
\hline 85 & 99.9 & 99.5 & 99.5 & 80.3 & 99.9 & 99.5 & 99.5 \\
\hline
\end{tabular}

Table 5. Floatability of $2 \times 10^{-4} \mathrm{~mol} \mathrm{~L}^{-1}$ of $\mathrm{Hg}^{2+}, \mathrm{Mn}^{2+}$ and $\mathrm{Cd}^{2+}$ ions in the presence of some selected foreign ions using $4 \times 10^{-4} \mathrm{~mol} \mathrm{~L}^{-1}$ of each thiosemicarbazide derivative and $1 \times 10^{-3} \mathrm{~mol} \mathrm{~L}^{-1} \mathrm{HOL}$ at $\mathrm{pH} \sim 5$.

\begin{tabular}{|c|c|c|c|c|c|c|c|}
\hline \multirow{2}{*}{$\begin{array}{l}\text { Foreign } \\
\text { iona }^{a}\end{array}$} & \multicolumn{4}{|c|}{ [Foreign ion] mg L-1; $\mathrm{Hg}^{2+}$ Floatability, (\%) } & \multicolumn{2}{|c|}{$\begin{array}{c}\text { [Foreign ion] mg L'-1; } \\
\text { Mn }^{2+} \text { Floatability, (\%) }\end{array}$} & \multirow{2}{*}{$\begin{array}{c}\text { [Foreign ion] mg L-1; } \\
\text { Cd }^{2+} \text { Floatability, (\%) } \\
\mathrm{H}_{2} \mathrm{APO}\end{array}$} \\
\hline & $\mathrm{H}_{2} \mathrm{PPS}$ & $\mathrm{H}_{2} \mathrm{PBO}$ & $\mathrm{H}_{2} \mathrm{APO}$ & $\mathrm{H}_{2} \mathrm{PPY}$ & $\mathrm{H}_{2} \mathrm{PPS}$ & $\mathrm{H}_{2} \mathrm{APO}$ & \\
\hline$\overline{\mathrm{Na}^{+}}$ & [20]; 100 & [5]; 99.9 & [5]; 99.5 & [70]; 100.0 & {$[5] ; 99.0$} & [5]; 99.1 & {$[5] ; 99.1$} \\
\hline $\mathrm{K}^{+}$ & [50]; 99.9 & {$[15] ; 99.9$} & [5]; 99.3 & {$[50] ; 99.9$} & [5]; 99.2 & [5]; 99.2 & [5]; 99.2 \\
\hline $\mathrm{Mg}^{2+}$ & [50]; 99.9 & {$[20] ; 100.0$} & [5]; 99.1 & [5]; 98.9 & [5]; 100.0 & {$[5] ; 100.0$} & {$[5] ; 100.0$} \\
\hline $\mathrm{Ca}^{2+}$ & [20]; 99.8 & {$[15] ; 100.0$} & {$[10] ; 98.7$} & {$[20] ; 99.0$} & {$[10] ; 100.0$} & [5]; 99.3 & [20]; 99.3 \\
\hline $\mathrm{Cl}^{-}$ & [15]; 99.7 & [8]; 98.8 & [8]; 98.8 & {$[108] ; 100.0$} & {$[16] ; 99.9$} & [8]; 99.9 & {$[8] ; 99.9$} \\
\hline $\mathrm{SO}_{4}^{2-}$ & [10]; 99.5 & {$[10] ; 99.0$} & [5]; 98.9 & [50]; 100.0 & {$[10] ; 99.8$} & [5]; 99.8 & [5]; 99.8 \\
\hline $\mathrm{HCO}_{3}^{-}$ & [30]; 99.5 & [20]; 99.5 & [20]; 99.2 & [10]; 98.6 & [20]; 99.9 & [10]; 99.5 & [20]; 99.5 \\
\hline $\mathrm{CH}_{3} \mathrm{COO}$ & [50]; 99.7 & [30]; 99.9 & [5]; 98.5 & [5]; 98.0 & [50]; 99.7 & [10]; 99.7 & [20]; 99.7 \\
\hline
\end{tabular}

a The cations are added in the form of their chloride while the anions are added as their sodium salts.

Table 6. Floatability of $\mathrm{Hg}^{2+}, \mathrm{Mn}^{2+}$ and $\mathrm{Cd}^{2+}$ ions added to some selected water samples using $4 \times 10^{-4} \mathrm{~mol} \mathrm{~L}^{-1}$ of each thiosemicarbazide derivative and $1 \times 10^{-3}$ mol $\mathrm{L}^{-1} \mathrm{HOL}$ at $\mathrm{pH} \sim 5$.

\begin{tabular}{|c|c|c|c|c|c|c|c|c|}
\hline \multirow{2}{*}{ Water sample, (Location) } & \multirow{2}{*}{$\begin{array}{c}{\left[\mathrm{M}^{2+}\right]} \\
\left(\mathrm{mg} \mathrm{L}^{-1}\right)\end{array}$} & \multicolumn{4}{|c|}{ Hg $^{2+}$ Floatability, (\%) } & \multicolumn{2}{|c|}{ Mn $^{2+}$ Floatability, (\%) } & \multirow{2}{*}{$\begin{array}{c}\text { Cd }^{2+} \text {, Floatability, (\%) } \\
\mathrm{H}_{2} \mathrm{APO}\end{array}$} \\
\hline & & $\mathrm{H}_{2} \mathrm{PPS}$ & $\mathrm{H}_{2} \mathrm{PBO}$ & $\mathrm{H}_{2} \mathrm{APO}$ & $\mathrm{H}_{2} \mathrm{PPY}$ & $\mathrm{H}_{2}$ PPS & $\mathrm{H}_{2} \mathrm{APO}$ & \\
\hline \multirow{2}{*}{ Distilled water } & 5 & 100.0 & 98.5 & 98.6 & 97.3 & 99.0 & 99.1 & 99.1 \\
\hline & 10 & 100.0 & 99.3 & 99.2 & 99.0 & 99.7 & 99.9 & 100.0 \\
\hline \multirow{2}{*}{ Drinking water (Mansoura City) } & 5 & 97.5 & 96.0 & 94.5 & 94.5 & 99.2 & 99.2 & 99.2 \\
\hline & 10 & 99.0 & 98.8 & 97.0 & 98.0 & 99.8 & 99.8 & 99.7 \\
\hline \multirow{2}{*}{ Nile water (Mansoura City) } & 5 & 97.5 & 97.0 & 94.5 & 100.0 & 100.0 & 100.0 & 100.0 \\
\hline & 10 & 99.3 & 99.0 & 97.1 & 100.0 & 100.0 & 99.9 & 100.0 \\
\hline \multirow{2}{*}{ Sea water (Gamasa) } & 5 & 93.8 & 92.5 & 91.5 & 85.8 & 100.0 & 99.3 & 99.3 \\
\hline & 10 & 95.0 & 95.0 & 95.3 & 89.1 & 100.0 & 99.8 & 99.9 \\
\hline \multirow[t]{2}{*}{ Sea water (Ras El-Barr) } & 5 & 87.5 & 98.5 & 81.5 & 93.0 & 99.9 & 99.9 & 99.9 \\
\hline & 10 & 89.0 & 99.5 & 84.3 & 94.9 & 100.0 & 100.0 & 100.0 \\
\hline \multirow[t]{2}{*}{ Lake water (Manzalah) } & 5 & 77.5 & 78.5 & 87.3 & 100.0 & 99.8 & 99.8 & 99.8 \\
\hline & 10 & 88.9 & 83.7 & 89.9 & 100.0 & 100.0 & 100.0 & 99.9 \\
\hline \multirow[t]{2}{*}{ Underground water (Cinbellaween City) } & 5 & 91.3 & 92.8 & 85.7 & 84.3 & 99.9 & 99.5 & 99.5 \\
\hline & 10 & 93.0 & 94.8 & 88.0 & 87.0 & 100.0 & 99.8 & 99.9 \\
\hline
\end{tabular}

1520-1540 $\mathrm{cm}^{-1}$ for sodium oleate. Therefore, oleic acid can interact with other systems, through hydrogen bonding, either in its un-dissociated (R-COOH) or dissociated (R-COO-) forms depending on the $\mathrm{pH}$ of the medium and according to the following:

$$
\begin{aligned}
& \mathrm{R}-\mathrm{COOH}+\mathrm{MHL}^{+}=\mathrm{R}-\mathrm{COOH} \ldots . \mathrm{LHM}^{+} \\
& \mathrm{R}-\mathrm{COO}+\mathrm{MHL}^{+}=\mathrm{R}-\mathrm{COO}-\ldots . \mathrm{LHM}^{+} \\
& \mathrm{R}-\mathrm{COOH}+(\mathrm{HL})_{2} \mathrm{M}=\mathrm{R}-\mathrm{COOH} \ldots .(\mathrm{HL})_{2} \mathrm{M} \\
& \text { R-COO- }+(\mathrm{HL})_{2} \mathrm{M}=\mathrm{R}-\mathrm{COO}-\ldots . .(\mathrm{HL})_{2} \mathrm{M}
\end{aligned}
$$

This view was checked by carrying out infrared analyses. The infrared spectra of the isolated complexes from the float layers (after good washing) have no absorption bands corresponding to oleic acid. This means that oleic acid may combine with metal-thiosemicarbazide chelates through weak bonds (hydrogen bonds) depending on the solution $\mathrm{pH}$ [53].

The combination of oleic acid surfactant with the metal thiosemcarbazides gives hydrophobic aggregates that float with the aid of air bubbles (created inside the flotation cell by slight shaking) to the surface of the solution [53].

\section{Conclusions}

This investigation presents thiosemcarbazide derivatives as organic chelates (which are not pollutant for water media and may have biological importance) for the separation of about $100 \%$ of $\mathrm{Hg}^{2+}, \mathrm{Mn}^{2+}$ and $\mathrm{Cd}^{2+}$ ions. This is accomplished by using the simple, rapid and inexpensive flotation technique. This technique is expected to be soon incorporated as a clean technology to treat water and wastewater The procedure is free from interferences, is not affected by raising the temperature up to $65^{\circ} \mathrm{C}$ (which enables its application to hot wastewater treatment without the need for cooling) making the process economical. It is also successfully applied to the recovery of $\mathrm{Hg}^{2+}, \mathrm{Mn}^{2+}$ and $\mathrm{Cd}^{2+}$ ions spiked into different environmental water samples. The flotation mechanism is based on the formation of hydrogen bonding between oleic acid surfactant and mercury-thiosemcarbazide complexes.

\section{References}

[1]. Sitting, M. Hand Book of Toxic and Hazardous Chemicals, Noyes Publications, Park Ridge, NJ, 1981.

[2]. Kadirvelu, K.; Thamaraislvi, K.; Namasivayam, C. Sep. Purif. Technol. 2001, 24, 497-505.

[3]. Hasar, H. J. Hazard. Mater. 2003, 97, 49-57.

[4]. Al-Asheh, S.; Duvnjak Z. Sep. Sci. Technol, 1997, 33, 1303-1329.

[5]. Gksungure, Y.; Uren, S.; Güvenc, U. Bioresource Technol. 2005, 96, 103 109.

[6]. Kim, J. S.; Akeprathumchia, S.; Wickrasinghe, S. J. Member. Sci. 2001, 182, 161- 172.

[7]. Blöcher, C.; Dorda, J.; Mavrov, V.; Chmiel, H.; Lazaridis, N. K.; Matis, K. A Water Res. 2003, 37, 4018-4026.

[8]. Ghazy, S. E. Sep. Sci. Technol. 1995, 30, 933-947.

[9]. Sorensen, E. M. B. Metal Poisoning in Fish, CRC Press Inc, Boca Raton, Florida, 1991

[10]. Ghazy, S. E.; Mostafa G.A. E. Canadian J. Anal. Sci. Spect. 2008 53, 28-35.

[11]. Chubar, N.; Carvalho, J. R.; Correia, M. J. N. Colloids and Surfaces A, 2003, 230, 57-65.

[12]. Aschner, M.; Erikson, K. M.; Dorman, D. C. J. Crit. Rev. Toxicol. 2005, 35, $1-32$. 
[13]. Quintanar, L. Inorg. Chim. Acta 2008, 361, 875-884.

[14]. Mizuike, A. Fresenius' J. Anal. Chem. 1986, 324, 672-677.

[15]. Leyden, D. E.; Wegscheider, W. Anal. Chem. 1981, 53, 1059A-1065A.

[16]. Zouboulis, A. I.; Lazaridis, N. K.; Zamboulis, D. Sep. Sci. Technol.1994, 29, 385-400.

[17]. Stoica, L.; Dinculescu, M.; Plapcianu, C.G. Water Res. 1998, 32, 30213030.

[18]. Rubio, J.; Souza, M. L.; Smith, R. W. Minerals Eng., 2002, 15, 139-155.

[19]. Doyle, F. M. Int. J. Miner. Process. 2003, 72, 387-399.

[20]. Doyle, F. M.; Liu, Z. J. Colloid Interface Sci. 2003, 258, 396-403.

[21]. Cora, M. G.; Hung, Y-T. Int. J. Environ. Eng. 2009, 1, 3-19.

[22]. Kidkoro, T.; Matusi, K.; Ishiwata, S.; Sasaki, T. Bull. Chem. Soc. Jpn. 1988, $61,1505-1508$.

[23]. Kabil, M. A. Fresenius J. Anal. Chem. 1994, 348, 246-247.

[24]. Voyce, D.; Zeitlin, H. Anal. Chim. Acta 1974, 69, 27-34.

[25]. Feng, X.; Ryan, D.E. Intern. J. Environ. Anal. Chem. 1985, 19, 273-280.

[26]. Ghazy, S. E.; Rakha, T.H.; El-Kady, E. M.; El-Asmy, A. A. Indian J. Chem Technol. 2000, 7,178-182.

[27]. Clarke, A. N.; Wilson, D. J. Sep. Purif. Reviews 1978, 7, 55 - 98.

[28]. Mathew, L.; Reddy, M. L.; Prasada Rao, T.; Iyer, C.S.P.; Damodaran, A.D. Microchimica Acta 1997, 127, 125-128.

[29]. Ghazy, S. E. Sep. Sci. Technol. 1994, 29, 935-941.

[30]. Ghazy, S. E.; Kabil, M. A.; Shallaby, A. M.; Ammar, N. S. Indian J. Chem. Technol. 2001, 8, 211-218.

[31]. Akl, M. A.; Khalifa, M. E.; Ghazy, S. E.; Hassanien, M. M. Anal. Sci. 2002 $18,1235-1240$

[32]. Pavlovska, G.; Čundiva, K.; Stafilov, T.; Zendelovska, D. Sep. Sci. Technol. 2003, 38, 1111-1124.

[33]. Ulewicz, M.; Walkowiak, W.; Krystyna Brandt, K.; Porwolik-Czomperlik, I. Sep. Sci. Technol. 2003, 38, 633-645.

[34]. Jurkiewicz, K. Colloids and Surfaces A 2006, 276, 207-212.

[35]. Scorzelli, I. B.; Fragomeni, A. L.; Torem, M.L. Minerals Eng. 1999, 12, 905-917.

[36]. Matis, K. A.; Zouboulis, A.I. Biotechnol. Bioeng. 2004, 44, 354-360.

[37]. Ulewicz, M.; Walkowiak, W.; Bartsch, R. A. Sep. Purif. Technol. 2006, 48 264-269.

[38]. Hiraide, M.; Ito, T.; Baba, M.; Kawaguchi, H.; Mizuike, A. Anal. Chem. 1980, 52, 804-807.

[39]. Mumallah, N. A.; Wilson, D. J. Sep. Sci. Technol. 1981, 16, 213-228.

[40]. Zendelovska, D.; Čundeva, K.; Stafilov, T. Microchimica Acta 2000, 135 1436-5073.

[41]. Tuzen, M.; Soylak, M. J. Hazardous Materials 2009, 162, 724-729.

[42]. Gregory, O. J.; Barnett, S. M.; Deluise, F. J. Sep. Sci. Technol. 1980, 15 1499-1512.

[43]. Moruzzi, R.; Reali, M. A. P.; Patrizzi, L. J. A Different View of Removing Iron and Manganese Complexes Using Dissolved Air Flotation, In Young Researchers, 2004, Edited by Lens. P.; Stuetz, R. IWA Publishing London, UK, pp. 259-266.

[44]. Ghazy, S. E.; Kabil, M. A. Bull. Chem. Soc. Jpn. 1994, 67, 474-478.

[45]. Marczenko, Z. Separation and Spectrophotometric Determination of Elements, John Wiley \& Sons, New York, Toronto 1986.

[46]. Mohsen, A.; Omar, M. E.; Labouta, I. M. ; Kasem, M. G.; Boudais, J. J. Pharm. Sci. 1983, 72, 1226-1228.

[47]. West, D. X.; Swearingen, J. K.; El-Swaf, A. K. Trans. Met. Chem. 2004, 29, 80-83.

[48]. Ghazy, S. E; Samra, S. E.; Mahdy, A. M.; El-Morsy, S. M. Anal. Sci. 2006 22, 377-382.

[49]. Klassen, V. I.; Mokrousov, V. A. An Introduction to the Theory of Flotation, Butterworths, London, 1963.

[50]. Caballero, M.; Cela, R.; Perez-Bustamante, J. A. Talanta 1990, 37, 275 300.

[51]. Ramachandra, R. S. Surface Chemistry of Froth Flotation, Vol. 2 Reagents and Mechanisms, 2nd ed., Kluer Academic/Plenum Puplishers, New York, 1982.

[52]. Pol'kin, S. I.; Berger, G. S.; Revazashavili, I. B.; Shchepkina, M. M. Izv. Vyssh. Ucheb. Zaved., Tsvet. Met., 1968, 11, 6-11.

[53]. Ghazy, S. E.; Mostafa, H. A.; El-Farra, S. A.; Fouda, A. S. Indian J. Chem Technol. 2004, 11, 787-792. 